\title{
Study in the Responses of Some Soybean (Glycine max L.) Cultivars Under Water Stress Condition
}

\author{
EDI PURWANTO \\ Faculty of Agriculture, Sebelas Maret University, Surakarta 57126.
}

Received: 9 December 2002. Accepted: 15 January 2003.

\begin{abstract}
These sets of experiments were conducted at Faculty of Agriculture Sebelas Maret University and the Central Experiment Station of Agricultural Faculty, Sebelas Maret University at Jumantono, Karanganyar, Central Java. The experiments were conducted under greenhouse, laboratory and field condition for each year, while the duration of this research was for two years. The specific objectives of the experiments were: (i) to determine the changes of some morpho-physiological characteristics of water stress soybean and those of unstressed plants at different growth stages; (ii) to evaluate relationship between morpho-physiological traits associated with water stress resistance and yield of soybean. in this study consists some experiments, there are: (i) about response of some soybean cultivars to water stress in screen house and field condition; (ii) about germination response of some soybean cultivars in different concentration of PEG; (iii) a bout recovery survival and recovery of soybean seedlings after heat treatment. The plants were well watered before the treatment. Based on the result of the experiments, the following conclusion could be made: (i) water stress reduced growth, yield and y ield components of all s oybean cultivars u sed; (ii) PEG induced water s tress resulted in lower germination, shorter root and shoot length, and increase root-shoot ratio; (iii) the ability of plants to recovery after heat stress have low correlation with drought resistance in this experiment; (iv) the determination of root shoot ratio in the seedling stage was shown to be suitable screening techniques used to study water stress resistance.
\end{abstract}

(C) 2003 Jurusan Biologi FMIPA UNS Surakarta

Key words: soybean (Glycine max L.), cultivars, water stress.

\section{INTRODUCTION}

Soybean (Glycine max L.) is one of the several legume crops that $\mathrm{c}$ an be grown in a wide range of land types, from typical upland fields to lowland areas after rice. Grain legumes have become increasingly important, not only because they are used as sources of dietary protein and vegetable oil, but also because they help maintain soil nutrient status, especially nitrogen (Liyanage and Martin, 1985).

In Indonesia, increased production of food crops such as corn, soybean, peanut, mungbean, have been given a higher priority, after self-sufficiency in rice was attained. Much effort has been used to attain self-sufficiency in these crops, especially corn and soybean, but because of various constrains such as low yielding cultivars, poor seed quality, weed competition, drought, etc., this goal could not be achieved (Sumarno, 1985).

Crop plants rarely attain their full genetic potential for yield because limitations imposed by environment. Like all crops, soybean cultivars respond differentially to a given set of environmental conditions. One of the most important factors, which affect crop growth, is rainfall or moisture.

Water availability to crops is one of the primary climatic variables limiting crops production (Christian- sen, 1982). About one third of the world's potentially arable land suffers from inadequate supply of water and in the other two third, crop yield are periodically reduced by drought (Kramer, 1980).

Parsons (1982) presented three ways, which plants respond to drought and these are morphological changes, physiological changes, and biochemical changes. Water deficits that often occur influence various physiological processes associated with crop growth, development and economical yield (Hsiao, 1973).

Responses to water stress condition have been reported to vary among species and between cultivars within a crop species. There are two ways to evaluate the tolerance of crops to water stress condition. The first is comparison of their dry matter yield under water stress condition and non stress condition and the other through their ability to avoid water stress condition, such as by leaf fall or movement (Yamada, 1984).

Drought is one of the most important problems contributing to the low yield of soybean. Therefore increased productivity requires the development of drought resistance in crop plants is important for physiologist and breeders facilitating selection and improvement work.

Producing a high-yielding cultivar with improved drought resistance has been one of the major goals in 
soybean breeding. To be successful, selection criteria that are associated with higher yield under drought that can be measured accurately in short time and period must be identified. Identification of traits, which contribute to drought resistance in crop plants, is important to facilitate selection and improvement of cultivar response to environmental stress such as drought.

To develop drought resistance of soybean plants, identification and understanding of morphophysiological factors that related are necessary. The ability to evaluate these drought responses within a reasonable time and period using small quantities of pianting materials will greatly facilitate future selection and improvement work. Finally, it will help to achieve a self-sufficiency of soybean.

The specific objectives of the experiments were: (i) to determine the changes of some morphophysiological characteristics of water $s$ tress s oybean and those of unstressed plants at different growth stages, (ii) to evaluate relationship between morphophysiological traits associated with drought resistance and yield of soybean.

\section{MATERIALS AND METHODS}

These sets of experiments were conducted at Faculty of Agricuiture Sebelas Maret University Surakarta and the Central Experiment Station of Agricultural Faculty, Sebelas Maret University, at Jumantono, Karanganyar, Central Java. The experiment was conducted under greenhouse, laboratory and field conditions for each year, while the duration of this research was for two years.

The experiment 1 was about response of some soybean cultivars to water stress in screen house and field condition. This experiment was arranged in randomized complete block design, with the treatments of soybean cultivars (using 6 cultivars namely: Wilis, Lokon, Krakatau, Raung, Galunggung, Dieng) and duration of drought at different growth stage.

The experiment 2 was about germination response of some soybean cultivars in different concentration of PEG. This experiment was based on the germination response of seeds on polyethylene glycol (PEG) at different concentration. PEG was used to simulate the water stress conditions. This experiment was based on the germination response of soybean seeds on PEG (Polyethyiene glycol) solution at different concentrations. The soybean seeds were sown in petridishes line with filter paper. The solutions of each petridish were depending on the concentration of PEG in accordance to the treatment stated in experimental design.

The experiment 3 was about recovery survival and recovery of scybean seedlings after heat treatment. The plants were well watered before the treatment. When the seedlings are two weeks old, these were placed in an oven and allowed to be heat stressed.
Percent recovery was determined using Duncan's Multiple Range Test. Simple regression and correlation was used to determine the relationship between traits and yield.

\section{RESULT AND DISCUSSION}

In general water stress reduced growth and yield of all soybean cultivars used as presented in figure 1. The reduction occurred when drought was imposed either at vegetative or reproductive stages of growth or both under screen house and field conditions.

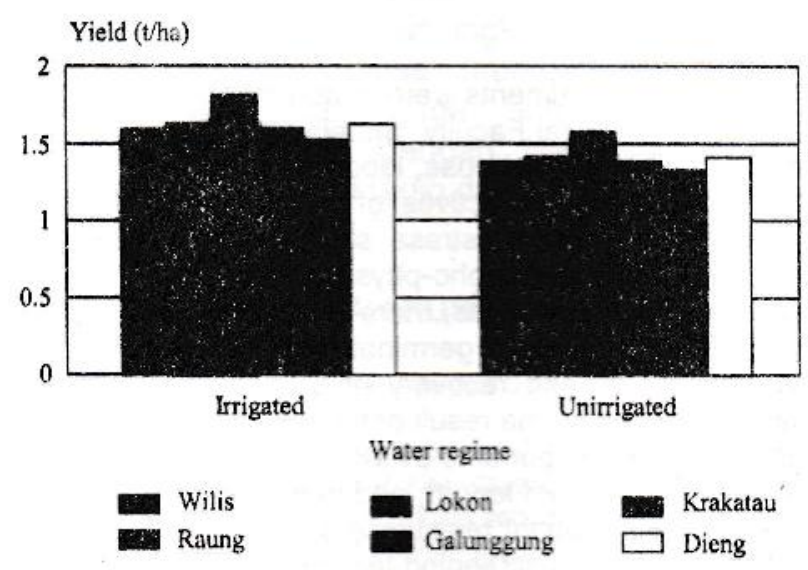

Figure 1. Seed yield of soybean under different water regimes.

Differences in grain yield were related to the number of pods and 100-seed weight. The number of pods of all cultivars was reduced when exposed to drought. This observation is similar to that reported by Pandey et al. (1984). Reduction in number of pods under drought condition may be due to reduced flower production and greater flower and pod abortion (Gardner et al., 1985). Water stress also reduced 100seed weight of all cultivars, as presented in Figure 2.

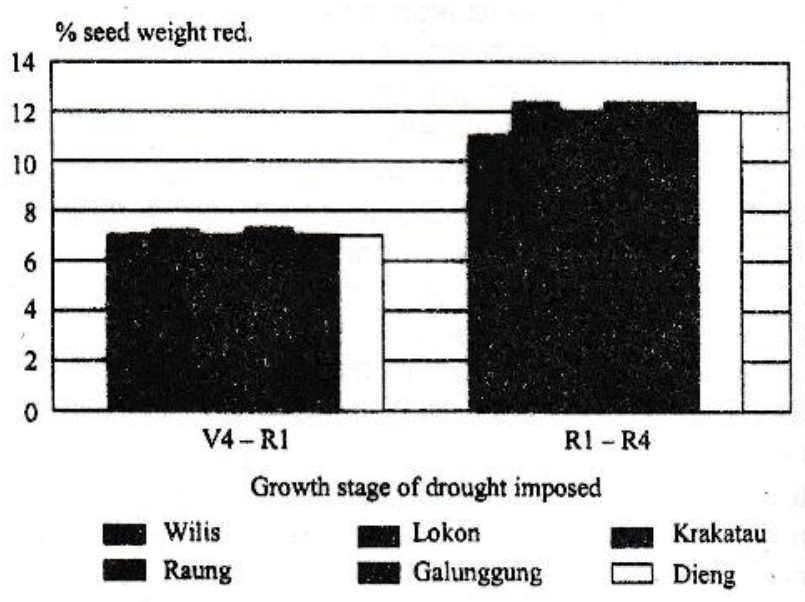

Figure 2. Seed weight reduction of soybean as affected by stage of growth when drought was imposed. 
Water stress aiso reduced 100-seed weight of all cultivars, as presented in Figure 2. This agrees with the report of Asley and Enthridge (1970) that found the seed size of n on-irrigated plants was s maller by volume (Hill, et al., 1986).

Water stress reduced leaf area of all cultivars used as presented Table 1. Begg (1980) stated that since water deficit adversely affects both cell division and enlargement, then one of the consequences of water deficit is reduction in leaf area.

Tabie 1. Leaf area of six soybean cultivars at different water regimes.

\begin{tabular}{|l|c|c|}
\hline Cultivar & Unstressed & Stressed \\
\hline Wilis & $1669 \mathrm{~b}$ & $1418 \mathrm{~d}$ \\
Lokon & $1981 \mathrm{~b}$ & $1422 \mathrm{~d}$ \\
Krakatau & $1712 \mathrm{a}$ & $1472 \mathrm{c}$ \\
Galunggung & $1654 \mathrm{~b}$ & $1408 \mathrm{~d}$ \\
Raung & $1668 \mathrm{~b}$ & $1410 \mathrm{~d}$ \\
Dieng & $1673 \mathrm{~b}$ & $1422 \mathrm{~d}$ \\
\hline
\end{tabular}

PEG induced water stress resulted in increase root-shoot ratio, as shown in Table 2.

Table 2. Root-shoot ratio as affected by different concentration of PEG across five soybean cultivars.

\begin{tabular}{|l|c|}
\hline PEG concentration & RS ratio \\
\hline Control & $1.9 \mathrm{~b}$ \\
75 & $2.2 \mathrm{~b}$ \\
100 & $2.5 \mathrm{a}$ \\
125 & $2.8 \mathrm{a}$ \\
\hline
\end{tabular}

Identification and understanding of morphophysiological factors related with drought resistance are important in improvement of drought resistance cultivars. So, ability to evaluate the screening techniques based on cultivars responses to water stress condition is important also.

Using simple correlation, some value of association between yield and other traits was calculated. From those values, some important association between drought resistance and some traits will be presented in Table 3.

Table 3. Association of yield and some morphophysiological traits in soybean under water stress.

\begin{tabular}{|c|l|c|}
\hline No. & The Traits & $\mathbf{R}$ Value \\
\hline 1. & Root-shoot ratio & 0.77 \\
2. & Net assimilation rate & 0.52 \\
3. & Percentage germination & 0.55 \\
4. & Growth recovery after heat treatment & 0.22 \\
\hline
\end{tabular}

From the result shows that among screening technique to study water stress, the determination of root-shoot ratio during seedling stage and PEG solutions were shown to be suitable ones for drought resistance in soybean.

The high value of correlation with drought resistance index should be high value to yield, because the drought resistance index was calculated based on yield reduction under stress.

\section{CONCLUSION}

Based on the result of the experiments, the following conclusion could be made: (i) water stress reduced growth, yield and yield components of all soybean cultivars used; (ii) PEG induced water stress resulted in lower germination, shorter roots and shoots length, and increase root-shoot ratio; (iii) the ability of plants to recovery after heat stress has low correlation with drought resistance in this experiment; (iv) the determination of root-shoot ratio in the seedling stage was shown to be suitable screening techniques used to study drought resistance.

\section{REFERENCE}

Ashley, D.A. and W.J. Ethridge. 1978. Irrigation effects on vegetative and reproductive development of three soybean cultivars. Agronomic Joumal 70: 467-471,

Begg, J.E. 1980. Morphological Adaptation of Leaves to Water Stress, in Adaptation to Water and High Temperature Stress. New York: Wiley interscience.

Christiansen, M.N. 1982. World environmental limitation to food and fiber culture. In: Breeding Plants for Less Favorable Environments. New York: John Wiley and Sons.

Gardner, F.P., R.B. Pearcea and R.L. Mitchel. 1985. Physiology of Crop Plants, lowa: lowa State University Press.

Hill, R.W., D.R. Johnson, and Ryan. 1979. A model for predicting soybean yield from climate data. Agronomic Journal 71:251. 256.

Hsiao, T.C. 1973. Technique for measuring water stress. Crops Science of America Special Publication 2:1-8.

Kramer, P.J. 1980. Drought, Stress and The Origin of Adaptations, in, Adaptation of Planis to Water and High Temperature Stress. New York: Wiley interscience.

Pandey, R.K., W.A.T. Herrera, And J.W. Pendieton. 1984. Drought response of grain legumes under irrigation gradient 1 : yield and yieid component. Agronomic Joumal 76: 549-553.

Parsons, L.R. 1982. Plants Responses to Water Stress, in, Breeding for Less Favorable Environments. New York: John Wiley and Sons.

Sumarno. 1985. Soybean Breeding for Multiple and Intensive Cropping Systems. Shanhua: AVROC.

Winter, S.R., J.T. Musick, and K.B. Porter. 1988. Evaluation of screening techniques for breeding drought resistance in winter wheat. Crops Science 28: 512-516.

Yamada, Y. 1984. Plant Nutrition under Water Stress Conditions, in Ecology and Management of Problem Soil in Asia. New York: John Wiley and Sons. 